\title{
Earnings Management Through Consolidation: Hutchison Telecommunication International Limited
}

${ }^{1}$ Chi-Keung Man, Aberdeen University, UK \& Hang Seng Management College, HK

\begin{abstract}
This paper uses a case study approach to analyze how three corporations; namely, Hutchison Whampoa Limited (HWL), Hutchison Telecommunication International Limited (HTIL), and Hutchison Telecommunication Hong Kong Holdings, managed earnings through consolidation. The author finds that $H W L$, by listing, reducing, and increasing its shareholding in HTIL, improved its levels of profitability during the study period of 20042010. Furthermore, HTIL spun off its Hong Kong and Macau businesses to improve its profitability directly and that of HWL indirectly. Finally, HWL privatized HTIL in 2010. The author demonstrates that although HTIL was listed on the Hong Kong Stock Exchange, HTIL and HWL improved their share performances by managing earnings through consolidation techniques.
\end{abstract}

Keywords: Earnings Management; Consolidation; Case Study

\section{INTRODUCTION OF CASE COMPANIES}

\section{Background of Hutchison Whampoa Limited (HWL)}

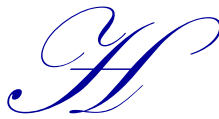

WL is a listed corporation in Hong Kong (stock code: 0013) that is considered to be one of the most technologically advanced and marketing-savvy telecommunications operators in Asia $^{1}$. As well as providing telecommunication services under three brands across 14 countries, it is also a leading port operator, retailer, and property and infrastructure developer. HWL is $49.97 \%$ owned by the Cheung Kong Group (Stock code: 0001), which is also listed on the Hong Kong Stock Exchange (SEHK). HWL's flagship companies include Hutchison Port Holdings, Hutchison Telecom, Hutchison Whampoa Properties, A.S. Watson, and Cheung Kong Infrastructure.

\section{Background of Hutchison Telecommunication International Limited (HTIL)}

$\mathrm{HTIL}^{2}$, which was listed on the SEHK between 2003 and 2010 (stock code: 2332), was a leading provider of telecommunication services in the world. The company offered mobile and fixed-line telecommunication services in Hong Kong, Macau, India, and Israel and mobile-only telecommunication services in Indonesia, Vietnam, Sri Lanka, and Thailand. Before its privatization in 2010, it was the first provider of 3G mobile services in Hong Kong and Macau and later provided GSM services in Vietnam and Sri Lanka and CDMA technology services in Indonesia and Thailand. In addition to being listed on the SEHK, its American Depositary Shares were also traded on the New York Stock Exchange (NYSE). HTIL became a wholly owned subsidiary of the HWL in mid- $2010^{3}$.

\footnotetext{
${ }^{1}$ Information from the firm website: http://www.hutchison-whampoa.com/eng/index.htm.

${ }^{2}$ For more information about Hutchison Telecom, see www.htil.com.

${ }^{3}$ Source: Modified from HWL's website: http://www.hutchison-whampoa.com/eng/about/milestones/1960.htm\#1960.
} 


\section{Background of Hutchison Telecommunication Hong Kong Holdings Limited (HTHK)}

Hutchison Telecommunication Hong Kong Holdings Limited (HTHK) is a listed company in Hong Kong Stock Exchange (Stock Code: 0215 ) by way of introduction. HTHK provides telecommunication services in Hong Kong under the brand name " 3 ". Its product range includes broadband, fixed-line communication, Wi$\mathrm{Fi}$, and IDD services to carrier customers in Hong Kong and overseas ${ }^{4}$. In 2010, HTHK was included in the Hang Seng Composite Industry Index (Telecommunications) and Hang Seng Composite Small Cap Index. For the year ending 2008, its turnover was USD 1,044 million and profit was USD 61 million before its listing on the SEHK (stock code: 0215). HTIL, a wholly owned subsidiary of HWL, holds a controlling stake in HTHK.

\section{COMPANY HISTORIES}

\section{History of HWL}

The origins of HWL can be traced back to the $19^{\text {th }}$ century merger of Hong Kong and Whampoa Dock, founded in Hong Kong in 1863, and Hutchison International founded in 1877. In 1960, Hutchison International acquired a controlling stake in Hong Kong and Whampoa Dock and later formed HWL in 1977. After running into financial difficulties, it was rescued by HSBC, which two years later sold it to the Cheung Kong Group. From the 1980s onward, HWL started to penetrate into different industries, including property development, retail, electricity supply, hotel and tourism, financial services, supermarkets, telecommunications, natural resources, broadcasting, infrastructure, and transportation through joint ventures or partnerships, acquisitions, and self-development (see Exhibit 1 in the Appendix for more details: HWL History 1970-2010).

As an example of its strategy to expand through acquisitions ${ }^{5}$, it acquired the PARKnSHOP supermarket chain in 1973 in order to provide a stable cash flow for HWL and its subsidiaries. In 1977, Hutchison International Limited merged with Hong Kong and Whampoa Dock Company Limited and three years later, HWL created the Hutchison Whampoa Property Group. In 1985, HWL acquired a controlling stake in Hong Kong Electric Holdings for USD 373 million. This became the engine of growth for HWL for the next 10 years because of the rapid economic development and resulting soaring demand for electricity in Hong Kong. In 1987, HWL acquired 43\% of Husky Oil in Canada while in 1990, Fortress joined the A.S. Watson Group. HWL also acquired substantial holdings in Felixstowe, Britain's premier container port, in 1990 and took a 50\% holding in a Shanghai container port two years later.

\section{History of HTIL}

Although HTIL was originally part of HWL, in 1999, Hutchison Telecom sold Orange and reinvested into 3G mobile services. In 2004, HWL spun off its telecommunication business (later renamed HTIL) and listed it on the SEHK. However, it kept its UK and European 3G businesses within HWL because they provided large cash flows for investing into 3G infrastructure. Besides its operations in Hong Kong and Macau, HTIL globalized its telecommunication business across Asia and the Middle East, including India, Israel, Sri Lanka, Indonesia, Vietnam, and Thailand (adopted from Exhibit 2 in the Appendix). In 2007, it sold a 67\% stake of its Indian business to Vodafone for USD 1.7 billion $^{6}$. Two years later, HTIL spun off HTHK and listed it on the SEHK (stock code: 0215) as its rate of return was too low. Spinning off and going public improved the profitability of HTIL (see Exhibit 3 in the Appendix and for further discussion, see the Case Analysis section).

\section{History of HTHK}

HTIL was granted a license to operate mobile services under the AMPS cellular radiotelephone network in 1984. In 1995, it launched GSM mobile services in Hong Kong and began to provide fixed-line services under the brand name HGC. In 2001, Hutchison Macau started providing GSM mobile services in

\footnotetext{
${ }^{4}$ Source: Modified from 2009 HTHK Annual Report P.4.

${ }^{5}$ Source: Modified from HWL's website: http://www.hutchison-whampoa.com/eng/about/milestones/1960.htm\#1960.

${ }^{6}$ From 2008 Annual report p. 35. 
Macau, while three years later it became the first operator to launch a $3 \mathrm{G}$ service in Hong Kong. HTIL now provides mobile services under the brand name "3". Hutchison Macau also provides 3G services in Macau (for more details, see the corporate structure of HTHK in Exhibit 4 in the Appendix).

\section{CASE ANALYSIS}

\section{Introduction to IAS 27 Accounting for Consolidation ${ }^{7}$}

Based on the definition provided by IAS 27, shareholders are the owners of a corporation. According to IAS 27, a corporation controls the composition of the board of the directors of another corporation, controls more than half of the voting power of another corporation, or holds more than half of the issued share capital of another corporation.

When one corporation (i.e., holding) acquires the control of another (i.e., subsidiary), its shareholders need to know the financial circumstances of not only the holding corporation, but also the group, in order to assess their investments. From the group's accounts, investors are thus able to assess the liquidity and financial stability or gearing of the group in order to aid investment decisions. Further, the unrealized profit arising from inter-company transactions can also be eliminated. IAS 27 thus has two aims: 1) to prepare and present the consolidated financial statements as a group under the controlling corporation and 2) to ensure the correct accounting treatment for investments in subsidiaries, joint controlled firms, and associates.

A holding corporation is required to present consolidated financial statements for all its subsidiaries except in the following three circumstances: 1 ) the parent is itself a wholly-owned subsidiary or is a partiallyowned subsidiary of another entity and its other owners, including those not otherwise entitled to vote, have been informed about, and do not object to the parent not presenting consolidated financial statements (see HTIL's annual report 2005); 2) when a parent corporation's equity instruments are not traded in a public market; or 3) when an ultimate or intermediate parent produces the consolidated financial statements in accordance with IFRS. Further, consolidated financial statements must be prepared under the same accounting policies while non-controlling interest must be separately shown under equity.

The partial disposal of an investment in a subsidiary can be classified into two cases:

1. When control is retained: Under these circumstances, the sale transaction is treated as one owner transferring his/her shares to another and thus no gain or loss on disposal is recognized. For example, HWL disposed of $29 \%$ of HTIL's interests to the public (for more details, see the Earnings Management section).

2. When control is not retained: Under these circumstances, parties need to recognize the gain or loss on the disposal of the shares in subsidiaries. This gain or loss is the difference between the fair value and carrying amount of the holding. For example, HWL sold $21 \%$ of HTIL's interest (for more details, see the HTIL's Share Performance after the Announcement of Earnings section). This is why the ownership, directly or indirectly through subsidiaries, of more than half of the voting or potential voting power of an investor does not constitute control.

\section{Disclosures Required in Consolidated Financial Statements}

- $\quad$ Nature of relationship between the parent and a subsidiary when the parent does not directly or indirectly own more than $50 \%$ voting power of a subsidiary.

- $\quad$ The reason why direct or indirect ownership through subsidiaries of more than $50 \%$ voting power of investee doesn't constitute the control.

- $\quad$ The reporting date of financial statements from a subsidiary and the reasons of difference when the date of such financial statements used by a subsidiary is different from the parent.

\footnotetext{
${ }^{7}$ Modified from Deloitte IAS Plus: Summary of International Financial Reporting Standards

(C) 2012 The Clute Institute http://www.cluteinstitute.com/
} 


\section{HTIL Listing in 2004}

In September 2004, HWL and HTIL were working on spinning off the telecommunication business in Hong Kong, India, Israel, Thailand, Sri Lanka, Paraguay, Ghana, and Macau listed on the SEHK. One month later, HTIL's American Depositary Shares began to be traded on the NYSE. Thereafter, based on HKAS 27, HTIL was required to prepare its consolidated financial statements, income statements, and cash flow statements for 2003 and 2004 for comparison purposes. All intra-company transactions also needed to be eliminated during the process of consolidation ${ }^{8}$ (for more details on IAS 27 and HKAS 27, please see the Introduction to IAS 27 Accounting for Consolidation section).

HWL primarily listed HTIL in order to sell $29 \%$ of its shares to the public and thus improve profitability, although it still needed to consolidate HTIL's financial reports in 2004 as it had retained $70 \%$ of the firm. Exhibit 5 (in the Appendix) shows that HTIL generated a low level of profit in 2004. If HWL had decided not to list HTIL, Hutchison would not have dripped down its profit as it would not have generated a gain on disposal of USD 527 million in the 2004 annual report. Thus, because it still held $100 \%$ of HTIL, return on sales would have decreased from $7.2 \%$ to $4.16 \%$ and shareholder profit would have decreased from USD 2,073 million to USD 1,558 million. Therefore, HWL wanted to list HTIL in 2004 in order to increase its overall profit.

Whether HWL held $70 \%$ or $100 \%$ of the shares, there was no great difference in assets and liabilities except cash and cash equivalents, which would have increased by USD 990 million following the disposal of approximately 30\% of HWL's interest in HTIL (see Exhibit 6 in the Appendix). Furthermore, retained earnings would have also increased the gain on disposal by USD 530 million. The remaining capital and reserves of HTIL would then transfer to non-controlling interest.

Moreover, after the consolidation of all HTIL companies' balance sheets and income statements, the return on equity, return on sales, and asset turnover of the group would have reduced by $4.72 \%, 4.16 \%$, and 2.07 times, respectively, compared with $6.18 \%, 7.2 \%$, and 0.208 times with $70 \%$ of HTIL (see Exhibit 6, Part B, in the Appendix). These ratios reflect the fact that listing HTIL would have increased shareholder profitability. Thus, HWL aimed to reduce the shareholding to $70 \%$ in order to improve the group's overall performance.

There were two other reasons behind the decision to list. First, the listing of HTIL generated an immediate gain of USD 0.53 billion, including sales of $4.2 \%$ to its business partner NTT DoCoMo. This profit was recorded in HWL's 2004 income statement. Second, HTIL going public helped the firm reduce its future cost of capital in order to acquire more telecommunication businesses from overseas. On 30 September 2004, the CEO of HTIL announced to the press (Apple Daily) that the intention to list HTIL was not to generate more cash, as HWL had more than $\$ 1.55$ billion in cash reserves at that time, but to acquire new funds to invest in telecommunication projects in East Asia, Eastern Europe, and the Middle East.

\section{HWL Reducing its Shares in HTIL in 2005}

During 2005, HWL sold $19.3 \%$ of its interest in HTIL, meaning that HTIL was no longer a subsidiary of HWL, as it owned only $49.8 \%$ of HTIL. Based on the accounting policy regarding consolidation introduced in the Introduction to IAS 27 Accounting for Consolidation section, a firm only treats a corporation as a subsidiary when the group directly or indirectly controls more than $50 \%$ of the equity voting rights or issued share capital ${ }^{9}$. Thus, HWL did not need to consolidate with HTIL because its voting rights and issued share capital was less than 50\% and it did not control the board of directors. Under the shareholder agreement, HWL

\footnotetext{
${ }^{8}$ Refer to 2004 Annual Report P.86 - 87.

${ }^{9}$ Please refer to HWL 2005 annual report p. 138.
} 
sold $19.3 \%$ of HTIL's interest to Orascom Telecom ${ }^{10}$, which nominated two non-executive directors onto the nine-member board of Hutchison Telecom. Apart from the three independent non-executive directors, HWL nominated two non-executive and two executive directors. In summary, HTIL no longer needed to consolidate with $\mathrm{HWL}^{11}$.

HWL disposed of a little under 50\% of its shares in HTIL in December 2005 in order to improve the group's performance. As discussed, if HTIL were still a subsidiary of HWL, according to HKAS 27, HWL would have needed to consolidate with it, thereby negatively affecting group performance in that year. Therefore, the group executed a strategic disposal during 2005 in order to realize significant cash proceeds and non-recurring profit. The sale to Orascom Telecom ${ }^{12}$ generated a profit of USD 951 million, which increased net profit in 2005 and increased cash by USD 1,298 million (equivalent to \$1.42 per HTIL share) on the balance sheet (see Exhibits 7 and 8). By contrast, without this disposal, HTIL's profit in 2005 would have reduced from USD 1,742 million to USD 781 million.

Table 1 shows that HWL decreased its holding percentage in HTIL to $49.8 \%$ in 2005 to increase earnings. Indeed, return on sales increased from $2.94 \%$ to $7.42 \%$ in 2005 by not consolidating with HTIL. At the end of 2006, HWL still held a less-than-50\% stake in HTIL (no change in owning percentage); however, its return on sales increased to $12.31 \%$. By contrast, if HWL had consolidated with HTIL, group performance would have deteriorated in 2006 (see Exhibit 9). Although return on equity for HTIL performed better than that for HWL, it improved little for the group (from $7.79 \%$ to $7.88 \%$ ). Therefore, it was reasonable for the firm not to increase its holding interest in HTIL in 2006 (see Table 2).

Table 1: 2005 Ratio Analysis

\begin{tabular}{|l|c|c|c|}
\hline \multicolumn{1}{|c|}{$\mathbf{2 0 0 5}$} & HTIL & HWL & HTIL + HWL \\
\hline Return on Equity & $-0.76 \%$ & $5.89 \%$ & $2.74 \%$ \\
\hline Return on Sales & $-0.61 \%$ & $7.42 \%$ & $2.94 \%$ \\
\hline Assets Turnover & 0.410 & 0.3058 & $32.01 \%$ \\
\hline Leverage & 2.006306 & 1.354 & 1.46 \\
\hline
\end{tabular}

Source: extracted from Exhibit 8 (in the Appendix)

Table 2: 2006 Ratio Analysis

\begin{tabular}{|l|c|c|c|}
\hline \multicolumn{1}{|c|}{$\mathbf{2 0 0 6}$} & HTIL & HWL & HTIL + HWL \\
\hline Return on Equity & $9.46 \%$ & $7.79 \%$ & $7.88 \%$ \\
\hline Return on Sales & $4.72 \%$ & $12.31 \%$ & $11.14 \%$ \\
\hline Assets Turnover & 0.419 & 0.271 & 0.287 \\
\hline Leverage & 3.439642 & 1.331719 & 1.44601984 \\
\hline
\end{tabular}

Source: extracted from Exhibit 9 (in the Appendix)

Aside from financial reasons, the strategic cooperation between Orascom Telecom and HTIL aligned their procurement processes, meaning that they enjoyed synergies in IT and software procurement, network equipment, international roaming, and transmitting costs. ${ }^{13}$ Furthermore, this synergy effect can be revealed from their operating areas. Orascom Telecom and Hutchison Telecom operated in 15 countries covering approximately two billion people and together served over 40 million mobile subscribers. Therefore, they could use each other's network systems to reduce their individual international roaming and transmitting costs.

\footnotetext{
${ }^{10}$ Orascom Telecom is a leading mobile telecommunications operator in emerging markets in the Middle East, Africa and South Asia. It was listed Cairo \& Alexandria Stock Exchange and London Stock Exchange. For more information about Orascom Telecom Holding please visit: www.orascomtelecom.com.

${ }^{11}$ Please refer to HWL 2005 annual report p. 208.

${ }^{12}$ See the joint announcement document: Orascom Telecom Acquires Strategic Stake in Hutchison Telecom.

${ }^{13}$ Orascom Telecom has operations in Algeria, Egypt, Pakistan and Bangladesh. It has a total population under license of nearly 460 million with an average mobile telephony penetration of $11.5 \%$.
}

(C) 2012 The Clute Institute http://www.cluteinstitute.com/ 


\section{HWL Increasing Shares of HTIL in 2007}

According to its 2005 annual report, HWL marginally increased its holding interest in HTIL from $49.8 \%$ to $50.1 \%$ in $2005^{14}$. This small purchase of shares in HTIL meant that HWL was now required to prepare consolidated financial statements in order to fulfill HKAS 27. Thus, HTIL was no longer an associate but a subsidiary of HWL.

The main reason behind this move toward preparing consolidated statements was to improve HWL's profitability. After increasing its shareholding in HTIL, HWL could reduce its loss for 2005 from a loss of USD 4,487 million to a profit of USD 4,224 million (see Exhibit 10 in the Appendix) by disposing of its Indian telecommunication business. This disposal generated huge gains, which improved the return on equity and return on sales ratios from $9.46 \%$ and $4.72 \%$ in 2006 , respectively, to $125 \%$ and $247 \%$, respectively, in 2007 (see Tables 2 and 3 ).

Table 3: Ratio Analysis for 2007

\begin{tabular}{|l|c|c|c|}
\hline \multicolumn{1}{|c|}{$\mathbf{2 0 0 7}$} & HTIL & HWL & HTIL + HWL \\
\hline Return on Equity & $125.20 \%$ & $-11.46 \%$ & $9.16 \%$ \\
\hline Return on Sales & $247.45 \%$ & $-18.25 \%$ & $15.03 \%$ \\
\hline Assets Turnover & 0.3584 & 0.265 & 0.2737 \\
\hline Leverage & 0.4117 & 1.373566 & 1.228 \\
\hline
\end{tabular}

Source: Extracted from Exhibit 10

After consolidation with HTIL in 2007 , the return on sales ratio also increased from $-18.25 \%$ to $15.03 \%$ (Table 3 ). On the contrary, without consolidation, HWL would have generated a negative return on equity of $11.46 \%$, which would have induced discontent among shareholders. Thus, by consolidating the group generated a positive return on equity of $9.16 \%$. In addition, it reduced HWL's financial leverage from 1.37 to 1.22, thereby improving the group's financial position in 2007 (see Exhibit 11 in the Appendix).

Return on equity and return on sales in 2007 were $125 \%$ and $247 \%$, respectively. These ratios were significantly higher than those in 2006 (9.46\% and 4.72\%, respectively) because disposing of the Indian business to a third party generated a huge profit in 2007 (Tables 2 and 3 and Exhibit 10). After consolidation, HWL increased its return on equity and return on sales ratios from $7.79 \%$ and $12.23 \%$ in 2006 to $9.16 \%$ and $15.03 \%$ in 2007 , respectively. This result not only turned a loss into a profit; it also increased HWL's shareholding in HTIL. From the point of view of investors, however, the 2007 annual report hid the profit on the disposal of this discontinued operation.

\section{Spin-off of HTHK}

In March 2009, HTIL distributed all share capital in HTHK. Each HTIL shareholder was allocated one share in HTHK for each one held in HTIL. In May 2008, HTIL agreed to spin off the Hong Kong and Macau telecommunication businesses listed on the SEHK. The CEO of HTHK resigned from HTIL, although other directors continued to operate HTIL's divisions in other Asian countries ${ }^{15}$. After listing HTHK, investors saw more stable profitability and cash flow with lower risk.

HTIL spun off the Hong Kong business and listed it on the SEHK because its return rate was too low in 2009. If the financial statements of HTHK had have been consolidated with those of HTIL, the return on sales for HTIL would have reduced from $39.94 \%$ to $27.53 \%$ and its return on equity would have reduced significantly from $48.28 \%$ to $29.6 \%$ (see Exhibit 3 ) as a result of the lower asset turnover of the Hong Kong business.

\footnotetext{
${ }^{14}$ Please refer to HWL 2005 Annual Report P.203.

${ }^{15}$ Source: iStockAnalyst.com: Hutchison Telecom: Successful Spin-Off and Listing of Hong Kong and Macau Operations on Hong Kong Stock Exchange.
} 
Therefore, HWL used this method to maintain a high returns growth rate for HTIL. However, it also created its own investor base, provided access to new sources of capital, and incentivized management ${ }^{16}$.

\section{EARNINGS MANAGEMENT AND SHARE PERFORMANCE}

\section{Earnings Management}

Earnings management is defined as the choice of accounting policies or other actions that affect earnings intentionally. This topic is an important research area as earnings management can undermine the credibility of financial statements which provide useful information for stakeholders in well-functioning capital markets. Most previous studies in the earnings management literature have focused on two types of general earnings management: 1) accruals management and 2) the manipulation of real economic activities. For discretionary accruals, firms can use provisions for credit losses, warranty costs, inventory values, and the timing and amounts of unusual items, whereas accruals earnings management may have the reverse effect. Another approach is to use real variables, although this may be costly and thus affect the firm's long-term interest. According to Graham et al. (2005), most respondents use real variables to manage the earnings.

Previous studies have explored the reasons behind decisions on earnings management, including compensation schemes (Healy, 1985; McNichols \& Wilson, 1988; Sloan, 1995), debt covenants (DeFond \& Jiambalvo, 1994; DeAngelo et al., 1994; Shores, 1995), investors' expectation meetings (Bartov, Givoly, \& Hayn, 2002; Barton \& Mercer, 2005), and better prices for IPOs (Hughes, 1986; Clarkson et al., 1992; Teoh, Welch, \& Wong, 1998). Although earnings management can reduce blocked communication, thus reveal inside information (Stocken \& Verrecchia, 2004). It can also result from opportunistic earnings management (Dechow, Sloan, \& Sweeney, 1996; Hanna, 1999). Previous studies have also found that severe earnings management and a low level of earnings informativeness are characteristics of weak investor protection institutions (DeFond, Hung, \& Trezevant, 2007; Leuz, Nanda, \& Wysocki, 2003).

However, no study has thus far investigated how a firm can manage earnings using consolidation techniques; namely, increasing a holding in a subsidiary in order to consolidate with it or reducing a holding in order not to. The present study fills the gap in the literature by analyzing an Asian firm; namely, HWL. Because few firms use the consolidation technique, the author applies the case study method to explore earnings management. However, the author cannot use statistical methods to quantitatively assess the relationship between this technique and share performance.

HWL used different financial techniques - including accounting for consolidation - to improve its profitability in different periods. As shown in the analysis above, in 2004 it listed HTIL on the SEHK and NYSE to improve profit levels. This, in turn, increased its return on sales, return on equity, and asset turnover ratios. In 2005, HWL sold almost half of its shares in HTIL in order to improve profit by avoiding consolidation. Once again, this measure improved the same profitability ratios. In 2007, HWL purchased a $0.3 \%$ share in HTIL's interests, which turned a loss of $\$ 4.37$ billion into a profit of $\$ 32$ billion through consolidation and the disposal of investments in the Indian business. This also turned these three ratios from negative to positive.

In 2009, the performances of the Hong Kong and Macau telecommunication businesses deteriorated. In that year, they only generated USD 68 million to HTIL, which significantly and directly affected HTIL and indirectly affected HWL's profitability. Once again, the group used the accounting for consolidation technique to spin off the Hong Kong and Macau businesses (termed HTHK), thereby improving the profitability of both HTIL and HWL. The group has thus continually applied accounting for consolidation to manage earnings across the study period. In the HTIL's Share Performance after the Announcement of Earnings section, because this technique is difficult for normal investors without accounting knowledge to investigate, the author describes HWL's share performance and profitability across the study period.

\footnotetext{
${ }^{16}$ Source: Listing Document by Introduction in 2009 p.7. 


\section{HTIL's Share Performance after the Announcement of Earnings}

Between 2004 and 2010, HTIL sold some of their businesses worldwide in order to improve profit levels. It also indirectly improved the profit of HWL in different years. For instance, in 2004 it disposed of all interest in Hutchison Global Communications Holdings Limited ${ }^{17}$ (from $79 \%$ to $52.5 \%$ ) through a placement to generate a gain on disposal of approximately USD 0.17 billion in the 2004 income statement ${ }^{18}$. Through this earnings management technique, the firm turned a loss for 2003 into a profit for 2004. In that same year, after the annual report had been released, the firm's share price rose rapidly - from $\$ 0.13$ per share to $\$ 0.21$ per share - by the end of 2005 .

In 2005, HTIL purchased an owning interest in Partner Communication Company Limited ("Partner") from $42.9 \%$ to $52.2 \%$. This purchase resulted in consolidation with Partner's financial statements, as it had become a subsidiary of HTIL. Because the acquisition payment to Partner was termed capital expenditure, it did not need to be accounted for in the income statement. However, as consolidation was required according to HKAS 27, Partner contributed a turnover of USD 850 million and a profit of USD 35 million to the group for the period from 20 April 2005 to 31 December 2005 (see Exhibit 12 in the Appendix). This increased profit from continuous operations from USD 192 million to 295 million. This method thus turned capital expenditure into recurring revenue, further increasing the share price of HTIL from \$0.25 per share in March 2006 (after the annual report had been announced) to $\$ 0.34$ per share at the end of 2006 . Therefore, this share performance was clearly affected by the acquisition of Partner.

In 2006, HTIL used the same method to acquire another corporation and again turn capital expenditure into recurring revenue. During 2006, a subsidiary of HTIL in India; namely, Hutchison Essar Limited, acquired an owning interest in BPL Mobile Cellular Limited as well as a 100\% stake in Essar Spacetel Private Limited ${ }^{19}$, while Partner acquired the transmission business of Med- $1^{20}$ in July 2006. These three acquisitions contributed a total of USD 170 million in turnover to HTIL ${ }^{21}$. In October 2007, the company sold its entire interest in Hutchison Essar Limited and its subsidiaries to Vodafone, generating a gain of 9,061 million. Therefore, HTIL turned a loss from continuous operations of USD 405 million into a profit for the year of USD 8,712 million. In May 2008, HTIL spun off the Hong Kong and Macau telecommunication businesses and listed them on the SEHK in order to maintain a high returns growth rate of HWL.

The management of HTIL used different financial techniques (earning management) to improve HTIL profit in different years. These methods are difficult for investors without accounting knowledge to look through. It is expected that share performance after the announcement of good news increased during that year. Therefore, the author thus used the HTIL daily closing share price with adjusted cash/stock dividends and the split after announcement date of the annual report for the 2004-2010 period to calculate the average cumulative returns for good news (i.e., the mean current year's profit is higher than that in the previous year) and bad news (i.e., the mean current year's profit is below that in the previous year).

After the announcement of good news (Day 0), HTIL's share price continued to rise until day 240, at which point the average cumulative returns was $32.8 \%$ for that period (see Exhibit 13 in the Appendix). Following a bad news announcement, HTIL's share price decreased for 230 days, with an average cumulative

\footnotetext{
${ }^{17}$ Before disposal, at 31 December 2003, the Group owned 37\% of Vanda Systems \& Communications Holdings Limited ("Vanda"), which was then accounted for as an associated company. In March 2004, Vanda acquired 100\% of the Group's fixed-line and data centre businesses, and was renamed as Hutchison Global Communications Holdings Limited ("HGCH"). The Group's stake in HGCH increased to $79 \%$ of the enlarged share capital of HGCH as a result of HGCH's acquisition of the fixed-line and data centre businesses. As of March 2004, HGCH was accounted for as a subsidiary company of the Group.

${ }^{18}$ Source: HTIL 2004 Annual Report P. 106 (Note 15).

${ }^{19}$ A company had a licence to operate areas in Madhya Pradesh, North East, Himachal Pradesh, Bihar, Orissa, Assam, and Jammu.

${ }^{20}$ Med-1 is a private company operating a fibre-optic network, a national communication infrastructure in Israel, and holds a licence to supply communication infrastructure services to Israeli companies.

${ }^{21}$ Source: 2006 Annual Report p.105.
} 
return of $-2 \%$ (see Exhibit 14 in the Appendix). This result is weaker because the sample size of bad news is only a two-year period during the overall study period of 2004-2010 (Figure 1).
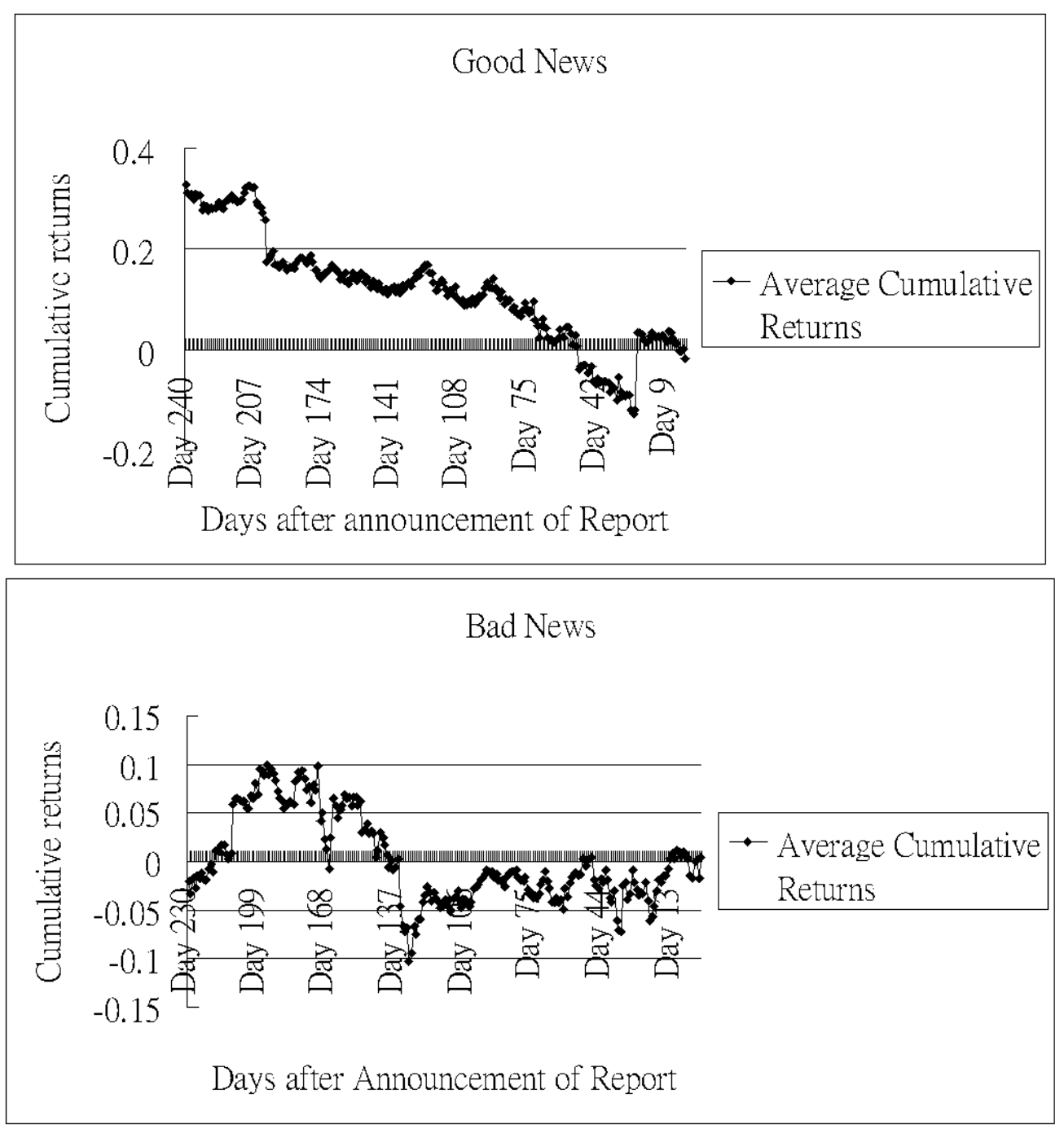

Figure 1: HTIL's Cumulative returns after announcements of good news \& bad news

\section{HWL's Share Performance after the Announcement of Earnings}

As previously mentioned, Hutchison Whampoa Limited used a different accounting technique to boast a profit for the years 2004-2010. For instance, HWL listed HTIL in 2004 to improve return on sales and equity. HWL reduced its shares holding of HTIL in 2005 to below 50\% to avoid consolidation with HTIL in order not to jeopardize HWL's profit in that year. HWL purchased only $0.3 \%$ shares of HTIL in 2007 to make its holding rise to above 50\% so as to consolidate with HTIL's financial statements and share it's USD 9,062 million gain on disposal of Hutchison Essar Limited and its subsidiaries to Vodafone Group Plc. HWL shared better performance of HTIL in 2009 after the spin-off of Hutchison Telecommunication Hong Kong Holdings in 2009.

These financial and accounting techniques are very difficult for an investor to realize. Next, the same method to calculate the average cumulative share return after the announcement of good news for HWL is 
applied in order to test whether it shows a similar result to the share performance of HTIL described in the HTIL's Share Performance after the Announcement of Earnings section. After the announcement of good news following the release of the annual report, HWL's share price rose from day 1 to day 188, at which points its average cumulative return was $21.6 \%$. This confirms that these accounting techniques are useful to boost HWL's share performance.

\section{CONCLUSION}

This paper analyzed three Hong Kong-listed corporations; namely, HWL, HTIL, and HTHK, over the period 2003-2010. HWL was listed in 2004 in order to improve its performance in 2004 and 2005. Thereafter, in 2007 HWL marginally increased its holding in HTIL in order to turn a loss into a positive profit. Furthermore, in 2009 HTIL spun off its Hong Kong and Macau telecommunication businesses and listed them on the SEHK in order to improve profitability. Finally, HWL privatized HTIL at USD 0.29 per share in 2010 in order to gain a large amount of remaining cash from HTIL. Although HTIL was listed on the SEHK, HTIL and HWL improved share performance through such earnings management techniques.

\section{ACKNOWLEDGEMENT}

The author would like to thank Professor Woody Wu (CUHK) for his supervision and helpful comments.

\section{AUTHOR INFORMATION}

Paholic Man is a PhD student at University of Aberdeen and a Lecturer in the Department of Accountancy of Hang Seng Management College in Hong Kong. He has teaching experience in Financial Accounting, Cost and Management Accounting, and Financial Statement Analysis. He has had solid professional and commercial working experience. He holds memberships with professional bodies in accounting and investment management such as Institute of Public Accountants in Australia (MIPA), Association of International Accountants (FAIA Acad), and Chartered Institute for Securities \& Investments in UK (MCSI). His educational accomplishments include Master of Accountancy from The Chinese University of Hong Kong, Master of Science in Accountancy from The Hong Kong Polytechnic University, and Bachelor of Business Administration in Accountancy from City University of Hong Kong. E-mail: kman@ @smac.edu.hk or paholic1@ yahoo.com.hk

\section{REFERENCES}

1. Barton, J. and M. Mercer, "To Blame or Not to Blame: Analysts' Reactions to External Explanations for Poor Financial Performance," Journal of Accounting and Economics (September, 2005) pp. 509533.

2. Bartov, E., D. Givoly, and C. Hayn, "The Rewards to Meeting or Beating Earnings Expectations," Journal of Accounting and Economics (June, 2002), pp. 173 - 204.

3. Clarkson, P., A. Dontoh, G.D. Richardson, and S. Sefcik," The Voluntary Inclusion of Earnings Forecasts in IPO Prospectuses," Contemporary Accounting Research (Spring 1992), pp. 601-626.

4. De Angelo, L.E., "Auditor Size and Auditor Quality," Journal of Accounting and Economics (December 1981), pp.183 -199.

5. Dechow, P.M., R.G. Sloan, and A.P. Sweeney, "Causes and Consequences of Earnings Manipulation: An Analysis of Firms Subject to Enforcement Actions by the SEC," Contemporary Accounting Research (Spring 1996), pp. 1-36.

6. Defond, M.L. and J. Jiambalvo, "Debt Covenant Violation and Manipulation of Accruals," Journal of Accounting and Economics (January 1994), pp. 145-176.

7. Graham, J.R., C.R. Harvey and S. Rajgopal, "The Economic Implications of Corporate Financial Reporting. " Journal of Accounting and Economics (December 2005), pp. 3-73.

8. Hanna, J.D., "Never Say Never," CA Magazine (August 1999), pp. 35-39.

9. Healy, P.M., "The Effect of Bonus Schemes on Accounting Decisions," Journal of Accounting and Economics (April 1985), pp. 85-107. 
10. Hughes, P.J., "Signalling by Direct Disclosure Under Asymmetric Information,” Journal of Accounting and Economics (June 1996), pp. 119-142.

11. Hutchison Telecommunication International Limited's 2004 - 2009 Annual Report from: http://www.hkexnews.hk/listedco/listconews/advancedsearch/search_delisted_main.asp

12. Hutchison Whampoa Limited's 2004 - 2010 Annual Report from http://www.hutchisonwhampoa.com/eng/investor/annual/annual.htm

13. Hutchison Telecommunication Hong Kong Holdings Limited's 2009 - 2010 Annual Report from http://www.hthkh.com/eng/ir/reports.php

14. Hutchison Telecommunication Hong Kong Holdings Limited's website http://www.hthkh.com/eng/aboutus/milestones.htm

15. Hutchison Whampoa Limited's website http://www.hutchison-whampoa.com/eng/index.htm

16. Hutchison Telecommunications International Limited - Wikipedia, the free encyclopedia

17. Hutchison Telecommunications Hong Kong Holdings Limited - Wikipedia, the free encyclopedia

18. Hutchison Whampoa Limited - Wikipedia, the free encyclopedia

19. Leuz, C., "IAS Versus US GAAP: Information Asymmetry - Based Evidence from Germany's New Market," Journal of Accounting Research (June 2003), pp. 445 - 472.

20. Mchichols, M. and G.P. Wilson, "Evidence of Earnings Management from the Provision for Bad Debts," Journal of Accounting Research (Supplement 1988), pp.1-31.

21. Sloan, R.G., "Do Stock Prices Fully Reflect Information in Accruals and Cash Flows About Future Earnings?" The Accounting Review (July 1996), pp. 289 - 315.

22. Stocken, P.C. and R.E. Verrecchia, "Financial Reporting System Choice and Disclosure Management," The Accounting Review (October 2004), pp. 1181- 1203.

23. Teoh, S.H., I. Welch, and T.J. Wong, "Earnings Management and the Long-Run Performance of Initial Public Offerings," The Journal of Finance (December 1998). pp. 1935 - 1974. 
APPENDIX

Exhibit 1: History of HWL for 1970 - 2010

\begin{tabular}{|c|c|c|}
\hline Areas & Year & Various Businesses exploring event \\
\hline Property & 1971 & $\begin{array}{l}\text { Hutchison Properties Limited (HPL) is incorporated to concentrate on property } \\
\text { development and related services. }\end{array}$ \\
\hline Supermarkets & 1973 & The Group acquires PARKnSHOP supermarkets. \\
\hline Retails & 1981 & $\begin{array}{l}\text { A S Watson becomes a wholly owned subsidiary of Hutchison Whampoa Limited with } \\
75 \text { retail food and non-food outlets. }\end{array}$ \\
\hline Telecommunication & 1983 & $\begin{array}{l}\text { Hutchison Telephone Company Limited is granted a licence to operate an Advanced } \\
\text { Mobile Phone Service (AMPS) cellular radio telephone network in Hong Kong. }\end{array}$ \\
\hline Electricity & 1985 & $\begin{array}{l}\text { HWL acquires a substantial interest in Hongkong Electric Holdings for HKD 2,900 } \\
\text { million. }\end{array}$ \\
\hline Natural Resources & 1987 & $\begin{array}{l}\text { HWL expands overseas with the acquisition of a } 43 \text { per cent interest in Canada's Husky } \\
\text { Oil. }\end{array}$ \\
\hline Television Services & 1990 & $\begin{array}{l}\text { Hutchvision Limited, a joint venture with Mr Li Ka-shing and family, is established to } \\
\text { launch and operate a pan-Asian multi-channel satellite television service. }\end{array}$ \\
\hline Radio Services & 1990 & $\begin{array}{l}\text { Metro Broadcast is awarded a license to operate Hong Kong's second commercial radio } \\
\text { station. }\end{array}$ \\
\hline Railways & 1993 & $\begin{array}{l}\text { The Group, in conjunction with Cheung Kong (Holdings) and other Chinese partners, } \\
\text { signs an agreement in June to build the 'East' section of the express-way between } \\
\text { Shenzhen and Shantou. }\end{array}$ \\
\hline Hotel & 1995 & $\begin{array}{l}\text { The Harbour Plaza Hotel, with } 415 \text { rooms and } 101 \text { serviced apartments, opens for } \\
\text { business. }\end{array}$ \\
\hline Financial Sevices & 1995 & $\begin{array}{l}\text { HWL, in partnership with OTB Card Company Limited, a subsidiary of Dao Heng } \\
\text { Bank Group Limited, and Visa International, launches the ComPass Card. }\end{array}$ \\
\hline Agricultural & 1998 & $\begin{array}{l}\text { In June, Hutchison Whampoa (China) Limited has teamed up with two Mainland } \\
\text { companies to develop a large scale, high-tech rice farm in Qiqihaer, Heilongjiang. }\end{array}$ \\
\hline Wines & 1998 & In June, Watson's opens Hong Kong's biggest wine cellar \\
\hline Network & & $\begin{array}{l}\text { On } 16 \text { December, Hutchison Whampoa and Cheung Kong (Holdings) together with } \\
\text { other investors, establishes TOM.COM LIMITED. }\end{array}$ \\
\hline
\end{tabular}

Exhibit 2: HTIL History of Globalization

\begin{tabular}{|l|l|}
\hline Region & Worldwide exploring event \\
\hline Hutchison India & Hutchison Essar Limited started operations under the brand name "Orange" in Mumbai. \\
\hline Hutchison Orange Israel & Even after selling the Orange Brand to France Telecom, they used Orange brand in Israel \\
\hline Hutchison Telecom Sri Lanka & $\begin{array}{l}\text { The company's Sri Lankan operation, commonly known as Hutch, is the country's youngest } \\
\text { and smallest operator, but is growing fast. }\end{array}$ \\
\hline 3 Indonesia & $\begin{array}{l}\text { In July 2005, Hutchison Telecom acquired a 60\% equity stake in PT Hutchison CP } \\
\text { Telecommunications. }\end{array}$ \\
\hline Vietnamobile & $\begin{array}{l}\text { In February 2005, Hutchison Telecom was granted an investment licence by the government } \\
\text { for the project. }\end{array}$ \\
\hline Hutch Thailand & $\begin{array}{l}\text { In 2000, Hutchison Telecom and CAT Telecom Public Company Limited entered into a joint } \\
\text { venture to provide exclusive marketing services for CAT Telecom's CDMA mobile } \\
\text { telecommunications in the Bangkok. }\end{array}$ \\
\hline
\end{tabular}


Exhibit 3: 2009 HKHTH and HTIL Balance Sheets

2009

\section{ASSETS}

Current assets

Cash and cash equivalents

Restricted cash

Trade and other receivables

Stocks

Derivative financial assets

Available-for-sale financial assets

Total current assets

Assets held for sale

Non-current assets

Fixed assets

Goodwill

Other intangible assets

Deferred tax assets

Interests in associates

Total non-current assets

Total assets

\section{LIABILITIES}

Current liabilities

Trade and other payables

Borrowings

Current income tax liabilities

Derivative financial liabilities

Total current liabilities

Non-current liabilities

Borrowings

Other non-current liabilities

Total non-current liabilities

Total liabilities
Other non-current assets

Interests in jointly-controlled entities

Deferred tax liabilities

HTIL HKHTH HTIL + HTHK

HTIL HTHK HTIL + HTHK

\begin{tabular}{cccccc}
540.23 & 34.45 & 574.68 & $17.97 \%$ & $1.51 \%$ & $10.87 \%$ \\
176.35 & 0.00 & 176.35 & $5.87 \%$ & & $3.33 \%$ \\
282.65 & 139.46 & 422.11 & $9.40 \%$ & $6.11 \%$ & $7.98 \%$ \\
5.66 & 20.57 & 26.22 & $0.19 \%$ & $0.90 \%$ & $0.50 \%$ \\
- & & & & & \\
271.72 & & 271.72 & $9.04 \%$ & & $5.14 \%$ \\
560.03 & & 560.03 & $18.63 \%$ & & $10.59 \%$ \\
$\mathbf{1 , 2 7 6 . 6 1}$ & $\mathbf{1 9 4 . 4 7}$ & $\mathbf{1 , 4 7 1 . 0 8}$ & $\mathbf{4 2 . 4 7 \%}$ & $\mathbf{8 . 5 2 \%}$ & $\mathbf{2 7 . 8 2 \%}$ \\
\hline
\end{tabular}

$42.47 \%$

$2,316.84$

$36.72 \%$

$6.98 \%$

$53.15 \%$

$43.81 \%$

$\quad 1,212.85$

788.56

$4.28 \%$

$25.36 \%$

$14.91 \%$

$128.66 \quad 43.19$

$287.15 \quad 170.69$

457.84

$3.25 \%$

$0.00 \quad 47.30$

47.30

$0.00 \%$

$7.48 \%$

$2.07 \%$

$8.66 \%$

$0.00 \quad 0.00$

$0.00 \quad 34.70$

34.70

\begin{tabular}{ll}
$1,729.56$ & $2,087.53$ \\
\hline $3,006.17$ & $2,282.01$ \\
\hline
\end{tabular}

$\mathbf{3 , 8 1 7 . 1 0}$

$5,288.17$

$91.48 \%$

$0.89 \%$

3,006.17

5,28

100
$\mathbf{1 0 0 . 0 0 \%} \quad \mathbf{1 0 0 . 0 0 \%} \quad \mathbf{1 0 0 . 0 0 \%}$

EQUITY

Capital and reserves attributable to equity holders of the Company

Share capital

Reserves

$154.76 \quad 154.76$

$1,384.32 \quad 1,116.84$

$803.60 \quad 426.35$

$1,229.95$

60.41

$26.73 \%$

$2.01 \%$

$18.68 \%$

$0.00 \%$

$23.26 \%$

$-\quad 0.00$

0.64

$0.02 \% \quad 0.00 \%$

$0.01 \%$

$0.00 \quad 0.00$

$\begin{array}{ll}864.65 & 0.00\end{array}$

864.65

$28.76 \%$

$16.35 \%$

\begin{tabular}{cccccc}
233.55 & 560.15 & 793.70 & $7.77 \%$ & $24.55 \%$ & $15.01 \%$ \\
- & 0.00 & & & & \\
368.89 & 76.48 & 445.37 & $12.27 \%$ & $3.35 \%$ & $8.42 \%$ \\
602.44 & 0.00 & 602.44 & $20.04 \%$ & & $11.39 \%$ \\
$\mathbf{1 , 4 6 7 . 1 0}$ & $\mathbf{1 , 0 8 0 . 9 8}$ & $\mathbf{2 , 5 4 8 . 0 7}$ & $\mathbf{4 8 . 8 0 \%}$ & $\mathbf{4 7 . 3 7 \%}$ & $\mathbf{4 8 . 1 8 \%}$ \\
\hline
\end{tabular}

Minority interest

$1,539.07 \quad 0.00$

0.00
-70.57

$1,539.07 \quad 1,201.03$ $\begin{array}{lr}3,006.17 & 2,282.01\end{array}$

Total equity and liabilities

1.8.

\begin{tabular}{cccc}
309.51 & $5.15 \%$ & $6.78 \%$ & $5.85 \%$ \\
$2,501.16$ & $46.05 \%$ & $48.94 \%$ & $47.30 \%$ \\
\hline $1,539.07$ & $51.20 \%$ & $0.00 \%$ & $29.10 \%$ \\
& & $-3.09 \%$ & $0.00 \%$ \\
$2,740.10$ & $51.20 \%$ & $52.63 \%$ & $51.82 \%$ \\
\hline $\mathbf{5 , 2 8 8 . 1 7}$ & $\mathbf{1 0 0 . 0 0 \%}$ & $\mathbf{1 0 0 . 0 0 \%}$ & $\mathbf{1 0 0 . 0 0 \%}$ \\
\hline
\end{tabular}


Exhibit 4: Corporate Structure

\section{CORPORATE STRUCTURE}

The following diagram includes all of the Group's major operating companies immediately upon the Listing:

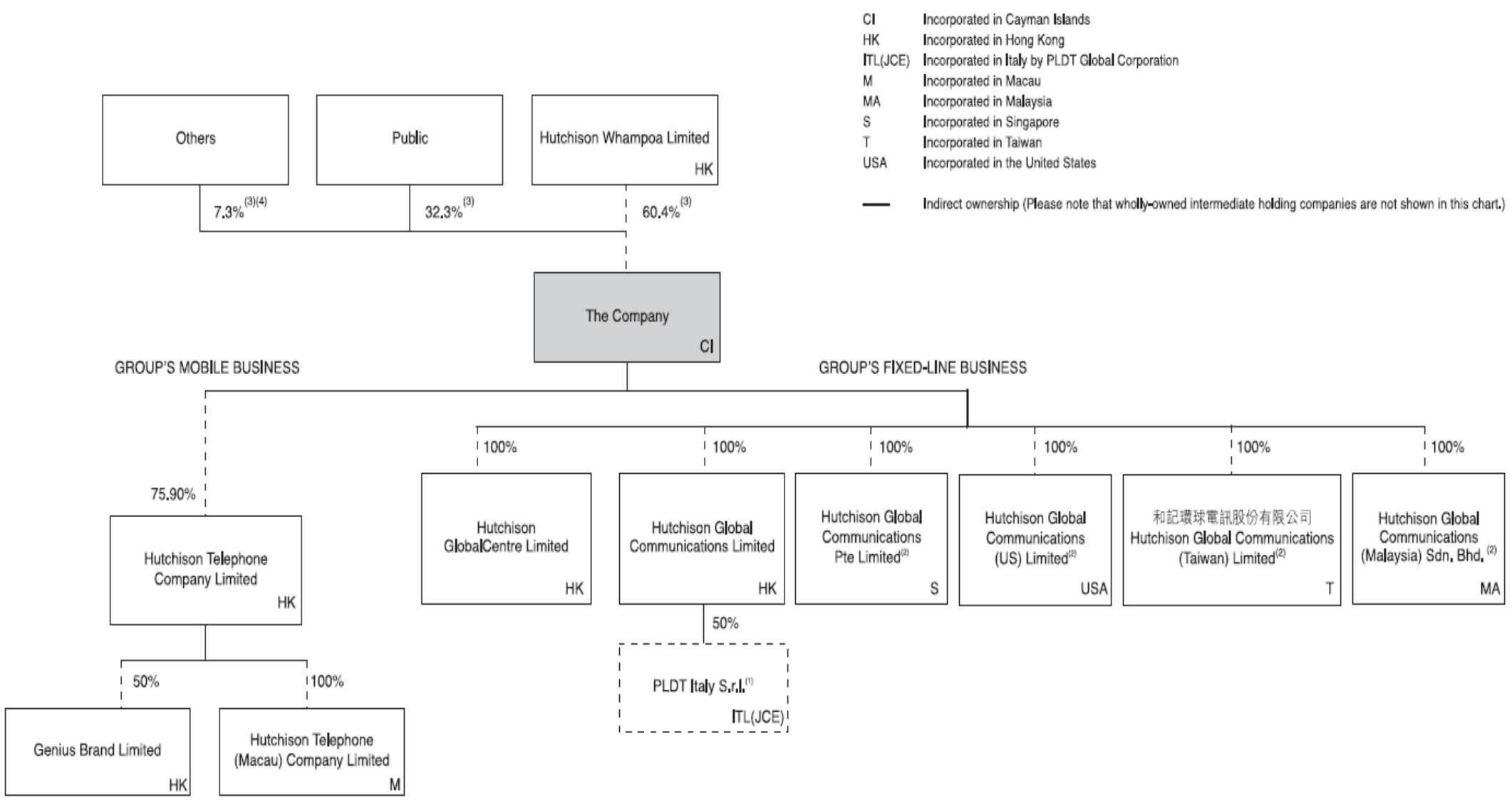


Exhibit 5: 2004 HTIL and HWL Income Statements

2004

Turnover

Cost of goods sold

Staff costs

Prepaid 3G telecommunication customer acquisition

Depreciation and amortisation

Other operating expenses

Change in value of properties

Profit on disposal of investments and others, net

Operating Profit

Share or profit less loss of associated companies

Share of profits less losses of jointly controlled entities

Net Interest and other finance costs

Profit before taxation

Taxation

Profit for the year from continuing operations

Minority interests

Profit attributable to shareholders
HWL + HWL + HTIL $70 \%$ HTIL $100 \%$ HTIL HTIL $70 \%$ HTIL 100\%

$\begin{array}{cccccc}1,923 & 17,300 & 17,300 & 100.00 \% & 100.00 \% & 100.00 \% \\ -180 & -6,685 & -6,685 & -9.36 \% & -38.64 \% & -38.64 \% \\ -205 & -2,767 & -2,767 & -10.68 \% & -15.99 \% & -15.99 \% \\ & -1,083 & -1,083 & & -6.26 \% & -6.26 \% \\ -393 & -3,890 & -3,890 & -20.45 \% & -22.48 \% & -22.48 \% \\ -1,169 & -4,972 & -4,972 & -60.82 \% & -28.74 \% & -28.74 \% \\ & 674 & 674 & & 3.90 \% & 3.90 \%\end{array}$

\begin{tabular}{cccccc}
167 & 2,465 & 1,938 & $8.69 \%$ & $14.25 \%$ & $11.20 \%$ \\
\hline & & & & & \\
142 & 1,044 & 517 & $7.39 \%$ & $6.04 \%$ & $2.99 \%$ \\
97 & 1,134 & 1,134 & $5.03 \%$ & $6.55 \%$ & $6.55 \%$ \\
& 311 & 311 & & $1.80 \%$ & $1.80 \%$ \\
\hline & 2,489 & 1,962 & & $14.39 \%$ & $11.34 \%$
\end{tabular}

Profit for the year

41

1,246

719

$-1,634$

$-7.05 \%$

$-9.44 \%$

$-9.44 \%$

\begin{tabular}{cccccc}
103 & 855 & 328 & $5.38 \%$ & $4.94 \%$ & $1.90 \%$ \\
-63 & 391 & 391 & $-3.27 \%$ & $2.26 \%$ & $2.26 \%$ \\
& & & & & \\
\hline 41 & 1,246 & 719 & $2.11 \%$ & $7.20 \%$ & $4.16 \%$ \\
\hline & & & & & \\
& 827 & 839 & & $4.78 \%$ & $4.85 \%$ \\
& 2,073 & 1,558 & & $11.98 \%$ & $9.01 \%$ \\
\hline $\mathbf{4 1}$ & $\mathbf{1 , 2 4 6}$ & $\mathbf{7 1 9}$ & $2.11 \%$ & $7.20 \%$ & $4.16 \%$ \\
\hline
\end{tabular}


Exhibit 6: 2004 HTIL and HWL Balance Sheets

2004

Non-current Assets

Fixed assets

Telecommunications licenses

Telecommunications $3 \mathrm{G}$

Goodwill

Associated companies

Interests in joint ventures

Deferred tax assets

Other non-current assets

Liquid funds and other listed investments

Total non-current assets

Cash and cash equivalent

Other current assets

Total Current Assets

Total Assets

Current liabilities
HWL + 70\% HTIL

27,113

13,128

877

1,316

7,112

4,622

2,492

1,058

8,548

66,266

9,486

8,340

$\mathbf{1 7 , 8 2 6}$

84,092

11,379
2,600

Non-current liabilities

Long term liabilities

Deferred tax liabilities

Pension obligations

Total non-current liabilities

Total Liabilities

CAPITAL AND RESERVES

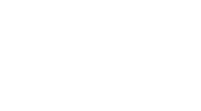

32,748

1,529

460

19

147

34,424

$\mathbf{4 5 , 8 0 2}$

$\mathbf{4 5 , 8 0 2}$

663
HWL +

HTIL

$100 \%$ HTIL

27,113

13,128

877

1,316

7,112

4,622

237

108

686

2,492

1,058

$$
8,548
$$

4,421

66,266

270

542

813

$\mathbf{5 , 2 3 4}$

2,660

\section{8,496}

8,340

$\mathbf{1 6 , 8 3 6}$

83,102

11,379

HWL + 70\% HTIL $32.24 \%$ $15.61 \%$

$1.04 \%$

$1.57 \%$

$8.46 \%$

$5.50 \%$

$2.96 \%$

$1.26 \%$

$10.17 \%$

$\mathbf{7 8 . 8 0 \%}$

11,379

$11.28 \%$

$9.92 \%$

$21.20 \%$ $100.00 \%$

$24.84 \%$

32,748

1,529

147

34,424

$\mathbf{3 , 3 2 3} \quad \mathbf{4 5 , 8 0 2}$

\begin{tabular}{ll}
$\mathbf{3 , 3 2 3}$ & $\mathbf{4 5 , 8 0 2}$ \\
\hline 1,836 & 33,000
\end{tabular}

9

HWL +

HTIL $100 \%$ HTIL

$49.68 \% \quad 32.63 \%$

$0.00 \% \quad 15.80 \%$

$0.00 \% \quad 1.06 \%$

$15.08 \% \quad 1.58 \%$

$4.53 \% \quad 8.56 \%$

$0.00 \% \quad 5.56 \%$

$2.07 \% \quad 3.00 \%$

$13.11 \% \quad 1.27 \%$

$0.00 \% \quad 10.29 \%$

$\mathbf{8 4 . 4 7 \%} \mathbf{7 9 . 7 4 \%}$

\begin{tabular}{cc}
$5.16 \%$ & $10.22 \%$ \\
$10.37 \%$ & $10.04 \%$ \\
$\mathbf{1 5 . 5 3 \%}$ & $\mathbf{2 0 . 2 6 \%}$ \\
\hline $\mathbf{1 0 0 . 0 0 \%}$ & $\mathbf{1 0 0 . 0 0 \%}$ \\
\hline $80.05 \%$ & $24.84 \%$
\end{tabular}

\section{Part B}

Return on Equity

Return on sales

Assets Turnover

Leverage

$2.13 \%$
$2.11 \%$
0.367387
1.739136

$6.18 \%$
$7.20 \%$
0.208

$4.72 \%$

$4.16 \%$

0.2057

1.387939597

1.366 
Exhibit 7: 2005 HTIL and HWL Balance Sheets

\begin{tabular}{|c|c|c|c|c|c|c|}
\hline \multirow{2}{*}{\multicolumn{7}{|c|}{$\begin{array}{l}2005 \\
\text { ASSETS }\end{array}$}} \\
\hline & & & & & & \\
\hline \multicolumn{7}{|l|}{ Current assets } \\
\hline Cash and cash equivalents & 313 & 6,390 & 5,405 & $4.09 \%$ & $8.33 \%$ & $6.50 \%$ \\
\hline Restricted cash & 0 & 0 & 0 & $0.00 \%$ & & \\
\hline Trade and other receivables & 1,287 & 4,629 & 5,915 & $16.80 \%$ & $6.03 \%$ & $7.12 \%$ \\
\hline Stocks & 88 & 2,614 & 2,702 & $1.15 \%$ & $3.41 \%$ & $3.25 \%$ \\
\hline Derivative financial assets & 1 & 0 & 1 & $0.02 \%$ & & \\
\hline \multirow[t]{2}{*}{ Available-for-sale financial assets } & - & 0 & & & & \\
\hline & 1,376 & 0 & 1,376 & & & $1.66 \%$ \\
\hline Total current assets & 1,689 & 13,633 & 14,024 & $22.06 \%$ & $17.77 \%$ & $16.87 \%$ \\
\hline Assets held for sale & - & & & & & \\
\hline \multicolumn{7}{|l|}{ Non-current assets } \\
\hline Fixed assets & 3,161 & 15,974 & 19,135 & $41.27 \%$ & $20.82 \%$ & $23.02 \%$ \\
\hline Goodwill & 1,245 & 2,308 & 3,553 & $16.26 \%$ & $3.01 \%$ & $4.27 \%$ \\
\hline Other intangible assets & 1,180 & 29,046 & 30,226 & $15.41 \%$ & $37.85 \%$ & $36.36 \%$ \\
\hline Other non-current assets & 266 & 569 & 835 & $3.47 \%$ & $0.74 \%$ & $1.00 \%$ \\
\hline Deferred tax assets & 118 & 2,021 & 2,139 & $1.54 \%$ & $2.63 \%$ & $2.57 \%$ \\
\hline Interests in associates & 0.25 & 8,398 & 7,129 & $0.00 \%$ & $10.94 \%$ & $8.58 \%$ \\
\hline Interests in jointly-controlled entities & - & 4,792 & 4,792 & & $6.24 \%$ & $5.76 \%$ \\
\hline Total non-current assets & 5,970 & 63,107 & 67,809 & $77.94 \%$ & $82.23 \%$ & $81.57 \%$ \\
\hline Total assets & 7,660 & 76,740 & 83,131 & $100.00 \%$ & $100.00 \%$ & $100.00 \%$ \\
\hline \multicolumn{7}{|l|}{ LIABILITIES } \\
\hline \multicolumn{7}{|l|}{ Current liabilities } \\
\hline Trade and other payables & 1,354 & 7,310 & 8,664 & $26.49 \%$ & $16.81 \%$ & $17.83 \%$ \\
\hline Borrowings & 988 & 3,346 & 4,334 & $19.34 \%$ & $7.69 \%$ & $8.92 \%$ \\
\hline Current income tax liabilities & 16 & 267 & 284 & $0.33 \%$ & $0.61 \%$ & $0.58 \%$ \\
\hline \multirow[t]{2}{*}{ Derivative financial liabilities } & 15 & & 15 & $0.29 \%$ & $0.00 \%$ & $\mathbf{0 . 0 3 \%}$ \\
\hline & 0 & & & & & \\
\hline Total current liabilities & 2,374 & 10,923 & 13,297 & $46.45 \%$ & $25.12 \%$ & $27.36 \%$ \\
\hline \multicolumn{7}{|l|}{ Non-current liabilities } \\
\hline Borrowings & 2,442 & 30,705 & 33,147 & $47.78 \%$ & $70.60 \%$ & $68.20 \%$ \\
\hline Deferred tax liabilities & 124 & 1,767 & 1,891 & $2.42 \%$ & $4.06 \%$ & $3.89 \%$ \\
\hline Other non-current liabilities & 171 & 96 & 268 & $3.35 \%$ & $0.22 \%$ & $0.55 \%$ \\
\hline Total non-current liabilities & 2,738 & 32,569 & 35,306 & $53.55 \%$ & $74.88 \%$ & $72.64 \%$ \\
\hline Total liabilities & 5,112 & 43,492 & 48,603 & $100.00 \%$ & $100.00 \%$ & $100.00 \%$ \\
\hline \multicolumn{7}{|c|}{ EQUITY } \\
\hline \multicolumn{7}{|c|}{ Capital and reserves attributable to equity holders of the Company } \\
\hline Share capital & 153 & 137 & 290 & $2.99 \%$ & $0.32 \%$ & $0.67 \%$ \\
\hline \multirow[t]{2}{*}{ Reserves } & 1,926 & 31,168 & 32,143 & $37.67 \%$ & $71.66 \%$ & $73.91 \%$ \\
\hline & 2,078 & 31,305 & 32,433 & $40.66 \%$ & $71.98 \%$ & $74.57 \%$ \\
\hline Minority interest & 469 & 1,295 & 1,417 & $9.18 \%$ & $2.98 \%$ & $3.26 \%$ \\
\hline Total equity & 2,548 & 32,600 & 33,850 & $49.84 \%$ & $74.96 \%$ & $77.83 \%$ \\
\hline Total equity and liabilities & 7,660 & 76,092 & 82,453 & $149.84 \%$ & $174.96 \%$ & $189.58 \%$ \\
\hline Net current assets/(liabilities) & 685 & $-2,710$ & $-2,025$ & $13.40 \%$ & $-6.23 \%$ & $-4.66 \%$ \\
\hline Total assets less current liabilities & 5,285 & 65,169 & $\mathbf{7 0 , 4 5 4}$ & $103.40 \%$ & $149.84 \%$ & $161.99 \%$ \\
\hline
\end{tabular}


Exhibit 8: 2005 HTIL and HWL Income Statements

2005

Turnover

Staff costs

Telecommunications prepaid customer acquisition cost

Depreciation and amortisation

Change in fair value of investment properties

Profit on disposal of investments and others, net

Operating Profit

Share of results of associated companies

Share of profits less losses of jointly controlled entities

Net Interest and other finance costs

Loss before taxation

Taxation

Loss on disposal of discontinued operations

Loss for the year
Cost of goods sold

Other operating expenses

HTIL HWL HTIL+HWL

HTIL

HWL HTIL+HWL

$\begin{array}{cccccc}3,138 & 23,468 & 26,607 & 100.00 \% & 100.00 \% & 100.00 \% \\ -301 & -8,072 & -8,374 & -9.59 \% & -34.40 \% & -31.47 \% \\ -299 & -3,307 & -3,606 & -9.53 \% & -14.09 \% & -13.55 \% \\ \text { osts } & -1,537 & -1,537 & 0.00 \% & -6.55 \% & -5.77 \% \\ -563 & -4,592 & -5,156 & -17.95 \% & -19.57 \% & -19.38 \% \\ -1,709 & -7,742 & -9,451 & -54.46 \% & -32.99 \% & -35.52 \% \\ & 474 & 474 & & 2.02 \% & 1.78 \% \\ 9 & 3,228 & 2,287 & & 13.76 \% & 8.59 \% \\ & & & & & \\ 266 & 1,920 & 1,235 & 8.47 \% & 8.18 \% & 4.64 \% \\ 11 & 1,037 & 1,058 & 0.35 \% & & \\ & 505 & 505 & & & \\ & & & & & \\ -206 & -1,980 & -2,186 & -6.57 \% & -8.44 \% & -8.22 \% \\ & & & & & \\ -80 & 1,482 & 461 & -2.54 \% & 6.31 \% & 1.73 \% \\ -56 & 261 & 205 & -1.78 \% & 1.11 \% & 0.77 \% \\ -43 & & -43 & -1.38 \% & & \\ -19 & 1,742 & 781 & -0.61 \% & 7.42 \% & 2.94 \%\end{array}$

Loss attributable to minority interests

$101 \quad 107$

Profit attributable to shareholders of the Company

889 
Exhibit 9: 2006 HTIL and HWL Income Statements

2006

HTIL HWL HTIL+HWL

HTIL HWL HTIL+HWL

Turnover

Cost of goods sold

$4,290 \quad 23,626$

$\begin{array}{ll}4,290 & -8,626 \\ -343 & -3,307\end{array}$

27,916

$100.00 \%$

(0).

$100.00 \%$

$-343 \quad-3,307$

$-8,923$

$-6.91 \%$

$100.00 \%$

$-31.96 \%$

Staff costs

$-706$

$-3,650$

$-7.99 \%$

$-36.51 \%$

$-13.07 \%$

$-706$

$-14.00 \%$

$-2.53 \%$

Depreciation and amortisation

$-652 \quad-4,253$

$-2,356$

$-6,537$

$-4,906$

$-8,893$

$-15.21 \%$

$-2.99 \%$

$-17.57 \%$

Other operating expenses

365

Impairment charge for Thailand segment

Profit on disposal of investments and others, net

$643 \quad 2,994$

365

$-54.92 \% \quad-27.67 \%$

$-31.86 \%$

$1.55 \%$

$1.31 \%$

Associated companies before profit on disposal of investments and others

share of profit on Jointly controlled entities

$395 \quad 395$

3,636

$14.98 \%$

$12.67 \%$

$13.03 \%$

395

1,475

$6.24 \%$

$1.42 \%$

share of profit on associated

1,475

(1,

Operating profit

Interest Income

Interest and other finance costs

$\begin{array}{cccccc}648 & 1,870 & 2,518 & 15.11 \% & 7.91 \% & 9.02 \% \\ 16 & & 16 & 0.36 \% & & 0.06 \% \\ -355 & -2,134 & -2,489 & -8.28 \% & -9.03 \% & -8.92 \% \\ & & & & & \\ 309 & 3,291 & 3,600 & 7.20 \% & 13.93 \% & 12.89 \% \\ -106 & 383 & 276 & -2.47 \% & 1.62 \% & 0.99 \% \\ 203 & 2,908 & 3,111 & 4.72 \% & 12.31 \% & 11.14 \%\end{array}$

Loss/ Profit for the year

$203 \quad 2,908$

Profit on disposal of discontinued operations

Loss/ Profit for the year

Loss attributable to minority interests

Profit attributable to shareholders of the Company

177

26

$-334$

2,575

$-157$

$4.12 \%$

$-0.56 \%$

Profit for the year

203

2,908

2,600

$0.60 \%$

$9.31 \%$

$4.72 \% \quad 12.31 \% \quad 11.14 \%$


Exhibit 10: 2007 HTIL and HWL Income Statements

2007

\begin{tabular}{llllll}
\hline HTIL & HWL & HTIL+HWL & HTIL & HWL & HTIL+HWL \\
\hline
\end{tabular}

Turnover

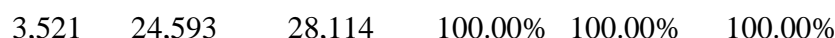

Cost of goods sold

$-351-9,158$

28,114

$100.00 \% \quad 100.00 \%$

$100.00 \%$

Staff costs

$-353-3,416$

$-3,769$

$-9.97 \% \quad-37.24 \%$

$-33.82 \%$

3 Group telecommunications expensed customer acquisition costs

Depreciation and amortisation

$0 \quad-737$

$-737$

$-10.04 \%-13.89 \%$

$-13.41 \%$

$\begin{array}{lll}-567 & -4,429 & -4,996\end{array}$

$0.00 \%-3.00 \%$

$-2.62 \%$

Other operating expenses

$-1,844 \quad-5,412$

$-7,256$

$-16.11 \%-18.01 \%$

$-17.77 \%$

Change in fair value of investment properties

Impairment charge for Thailand segment

$0 \quad 256$

$-495 \quad 495$

Profit on disposal of investments and others, net

$1 \quad-1,438$

256

$-52.37 \%-22.01 \%$

$-25.81 \%$

$-1,437$

$-14.07 \%-1.04 \%$

$0.91 \%$

Associated companies before profit on disposal of investments

Jointly controlled entities

Associated company's profit on disposal of an investment and others

$1,543 \quad 1,543$

$0.03 \%-5.85 \%$

$0.00 \%$

$\begin{array}{cc}429 & 429 \\ 4,604 & 4,604\end{array}$

$6.27 \%$

$5.49 \%$

$1.74 \%$

$1.53 \%$

Operating profit

$-89 \quad 7,330$

7,241

$-2.53 \% \quad 29.81 \%$

$25.76 \%$

Interest and other finance costs

$-41 \quad-2,408$

$-2,449$

$-1.18 \% \quad-9.79 \%$

$-8.71 \%$

Loss/ Profit before taxation

$-130 \quad 4,923$

4,792

$-3.71 \% \quad 20.02 \%$

$17.05 \%$

$\begin{array}{ll}-71 & -497\end{array}$

$-568$

$-2.02 \% \quad-2.02 \%$

$-2.02 \%$

Loss/ Profit for the year

$-201 \quad 4,426$

4,224

$-5.72 \% \quad 18.00 \%$

$15.03 \%$

$8,913 \quad-8,913$

Profit on disposal of discontinued operations

$8,712 \quad-4,487$

$\mathbf{4 , 2 2 4} 247.45 \%-18.25 \%$

$15.03 \%$

Profit for the year

$\mathbf{8 , 7 1 2}-\mathbf{- 4 , 4 8 7}$

4,224

$247.45 \%-18.25 \%$

$15.03 \%$ 
Exhibit 11: 2007 HTIL and HWL Balance Sheets

2007

ASSETS

Current assets

Cash and cash equivalents

Restricted cash

Trade and other receivables

Stocks

Derivative financial assets

Available-for-sale financial assets

Total current assets

Assets held for sale

Non-current assets

Fixed assets

Goodwill

Other intangible assets

Other non-current assets

Deferred tax assets

Interests in associates

Interests in jointly-controlled entities

Total non-current assets

Total assets

LIABILITIES

Current liabilities

Trade and other payables

Borrowings

Current income tax liabilities

Derivative financial liabilities
HTIL HWL + HTIL HWL

HTIL HWL + HTIL HWL

$\begin{array}{llllll}4,706 & 14,307 & 9,601 & 47.91 \% & 13.93 \% & 10.33 \%\end{array}$

$\begin{array}{llllll}- & 7,117 & 6,513 & 6.15 \% & 6.93 \% & 7.01 \%\end{array}$

$\begin{array}{llllll}66 & 2,699 & 2,633 & 0.67 \% & 2.63 \% & 2.83 \%\end{array}$

$\begin{array}{lllll}3 & -3 & 0.03 \% & 0.00 \% & 0.00 \%\end{array}$

$\begin{array}{lllll}- & & & & \\ 674 & -674 & 6.86 \% & 0.00 \% & -0.73 \%\end{array}$

\begin{tabular}{llllll}
$\mathbf{5 , 3 8 0}$ & $\mathbf{2 4 , 1 2 3}$ & 18,744 & $54.76 \%$ & $23.48 \%$ & $20.18 \%$ \\
\hline
\end{tabular}

$\begin{array}{llllll}- & & & & & \\ 2,179 & 23,309 & 21,130 & 22.18 \% & 22.69 \% & 22.74 \%\end{array}$

$\begin{array}{llllll}780 & 4,051 & 3,271 & 7.94 \% & 3.94 \% & 3.52 \%\end{array}$

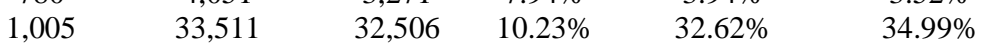

$\begin{array}{llllll}431 & 653 & 222 & 4.39 \% & 0.64 \% & 0.24 \%\end{array}$

$\begin{array}{llllll}48 & 2,265 & 2,216 & 0.49 \% & 2.20 \% & 2.39 \%\end{array}$

$\begin{array}{lllll}9,710 & 9,710 & 0.00 \% & 9.45 \% & 10.45 \%\end{array}$

$\begin{array}{lllll}5,106 & 5,106 & 0.00 \% & 4.97 \% & 5.50 \%\end{array}$

$\begin{array}{lllll}\mathbf{7 8 , 6 0 5} & 74,161 & 45.24 \% & 76.52 \% & 79.82 \%\end{array}$

$\begin{array}{lllll}102,728 & 92,905 & 100.00 \% & 100.00 \% & 100.00 \%\end{array}$

9,823

102,728

$100.00 \%$ $100.00 \%$

\begin{tabular}{|c|c|c|c|c|c|c|}
\hline Total current liabilities & 1,699 & 18,332 & 16,633 & $59.29 \%$ & $32.37 \%$ & $30.94 \%$ \\
\hline \multicolumn{7}{|l|}{ Non-current liabilities } \\
\hline Borrowings & 763 & 33,430 & 32,667 & $26.64 \%$ & $59.03 \%$ & $60.76 \%$ \\
\hline Deferred tax liabilities & 75 & 2,308 & 2,233 & $2.62 \%$ & $4.08 \%$ & $4.15 \%$ \\
\hline Other non-current liabilities & 328 & 2,558 & 2,231 & $11.45 \%$ & $4.52 \%$ & $4.15 \%$ \\
\hline Total non-current liabilities & 1,166 & 38,297 & 37,131 & $40.71 \%$ & $67.63 \%$ & $69.06 \%$ \\
\hline Total liabilities & 2,865 & 56,628 & 53,764 & $100.00 \%$ & $100.00 \%$ & $100.00 \%$ \\
\hline \multicolumn{7}{|c|}{ EQUITY } \\
\hline \multicolumn{7}{|c|}{ Capital and reserves attributable to equity holders of the Company } \\
\hline Share capital & 154 & 137 & -17 & $5.36 \%$ & $0.24 \%$ & $-0.03 \%$ \\
\hline Reserves & 6,438 & 39,711 & 33,272 & $224.75 \%$ & $70.12 \%$ & $61.89 \%$ \\
\hline Minority interest & 367 & 6,252 & 5,886 & $12.80 \%$ & $11.04 \%$ & $10.95 \%$ \\
\hline Total equity & 6,958 & 46,100 & 39,142 & $242.90 \%$ & $81.41 \%$ & $72.80 \%$ \\
\hline Total equity and liabilities & 9,823 & 102,728 & 92,905 & $342.90 \%$ & $181.41 \%$ & $172.80 \%$ \\
\hline Net current assets/(liabilities) & 3,681 & 5,792 & 2,111 & $128.50 \%$ & $10.23 \%$ & $3.93 \%$ \\
\hline Total assets less current liabilities & 8,124 & 84,397 & 76,272 & $283.61 \%$ & $149.04 \%$ & $141.87 \%$ \\
\hline
\end{tabular}


Exhibit 12: 2004 - 2009 HTIL comparative Income Statements

Continuing operations:

Turnover

Cost of goods sold

Staff costs

Depreciation and amortisation

Other operating expenses

Impairment charge for Thailand segment

Profit on disposal of investments and others, net

Operating loss

Interest income

Interest and other finance costs

Loss before taxation

Taxation

Loss for the year from continuing operations

Discontinued operations:

Profit for the year from discontinued operations

Profit for the year

Attributable to:

Equity holders of the Company:

- continuing operations

- discontinued operations

Minority interest:

- continuing operations

- discontinued operations

Dividends

Loss per share from continuing operations attributable to equity holders

of the Company

- basic

- diluted

\begin{tabular}{|c|c|c|c|c|c|}
\hline 2004 & 2005 & 2006 & 2007 & 2008 & 2009 \\
\hline 1,908 & 3,131 & 2,304 & 2,622 & 232 & 239 \\
\hline-176 & -300 & -278 & -343 & & \\
\hline-204 & -298 & -244 & -295 & -50 & -44 \\
\hline-401 & -561 & -489 & -543 & -87 & -91 \\
\hline$-1,146$ & $-1,704$ & $-1,116$ & $\begin{array}{c}-1,309 \\
-495\end{array}$ & -392 & -424 \\
\hline 211 & 9 & 6 & 1 & 192 & 54 \\
\hline 192 & 277 & 182 & -362 & -104 & -266 \\
\hline 3 & 8 & 8 & 208 & 115 & 2 \\
\hline-134 & -215 & -212 & -172 & -94 & -84 \\
\hline 62 & 82 & -22 & -326 & -83 & -348 \\
\hline-24 & -56 & -84 & -25 & -10 & -4 \\
\hline 38 & 26 & -106 & -350 & -94 & -352 \\
\hline-7 & -45 & 308 & 9,062 & 308 & 1,095 \\
\hline 31 & -19 & 203 & 8,712 & 214 & 743 \\
\hline 3 & -53 & -153 & -404 & -36 & -333 \\
\hline-7 & -45 & 179 & 9,001 & 182 & 968 \\
\hline 35 & $\begin{array}{c}79 \\
0\end{array}$ & $\begin{array}{c}47 \\
129\end{array}$ & $\begin{array}{l}54 \\
61\end{array}$ & $\begin{array}{l}-57 \\
126\end{array}$ & $\begin{array}{l}-19 \\
127\end{array}$ \\
\hline 0 & 0 & 0 & 4,143 & 4,332 & 1,315 \\
\hline & $(\mathrm{HK} \$ 0.01)$ & $(\mathrm{HK} \$ 0.03)$ & $(\mathrm{HK} \$ 0.08)$ & $(\mathrm{HK} \$ 0.01)$ & $(\mathrm{HK} \$ 0.07)$ \\
\hline $\mathrm{HK} \$ 0.01$ & $(\mathrm{HK} \$ 0.01)$ & $(\mathrm{HK} \$ 0.03)$ & $(\mathrm{HK} \$ 0.08)$ & $(\mathrm{HK} \$ 0.01)$ & $(\mathrm{HK} \$ 0.07)$ \\
\hline
\end{tabular}




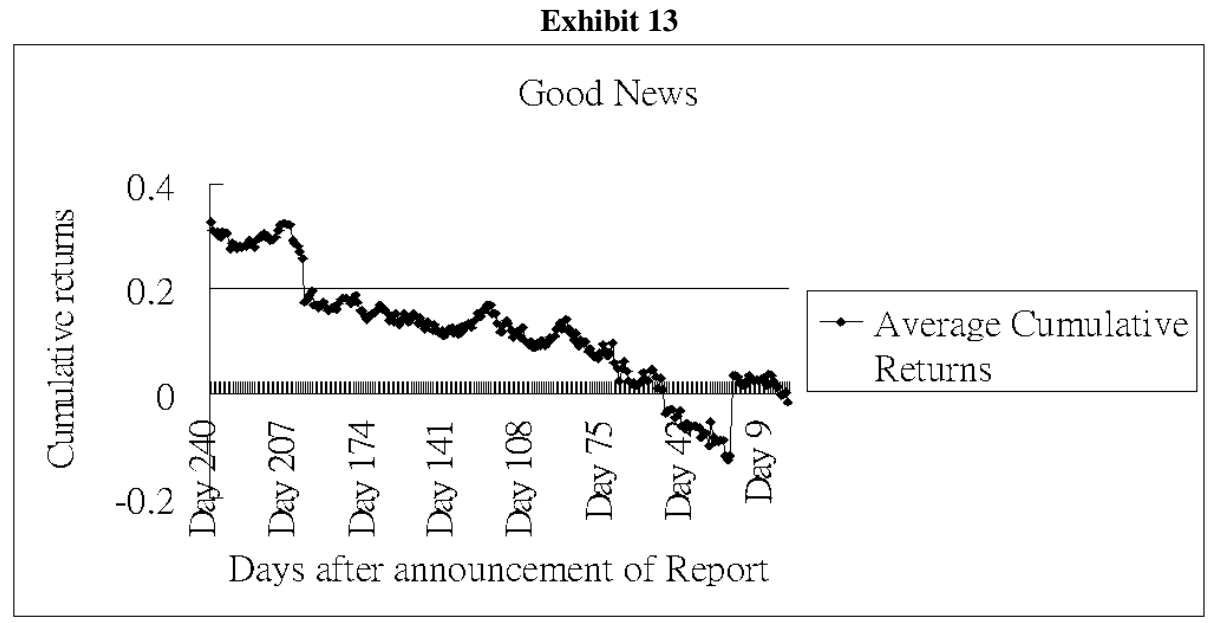

Exhibit 14

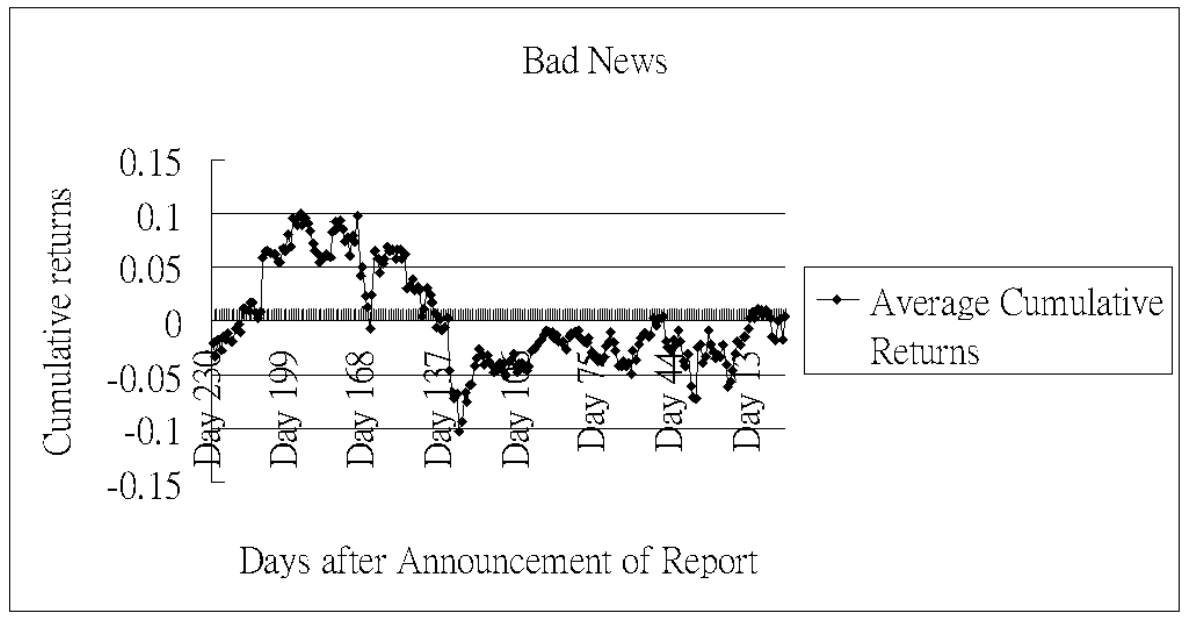




\section{NOTES}

